\title{
Saskatchewan Birds in Summer
}

\section{As Noted.by J. Murray Speirs and Dorothy H. Speirs, in July, 1953.}

On the morning of July 13, Mr. J. M. Speirs, Secretary of the Great Lakes Research Committee and Mrs. Speirs left Lloydminster for a rnotor trip across Saskatchewan with the airect intention of listing all birds that they saw on the way. The Manitoba border was reached about ten o'clock of the morning of July 16, and during that short period they recorded 2,708 individuals of 86 species.

The route from Lloydminster led through Maidstone, Battleford, North Battleford, Radisson, Saskatoon, Kenaston, Chamberlain, Lumsden, Regina, Qu'Appelle, Fort Qu'Appelle, Melville and Yorkton.

Unfortunately space does not permit a detailed statistical report of species observed at and between the centres named. The full report, however, may be seen at or loaned from the Provincial Museum.

The coverage is remarkable for the time available, and although the list is by no means a complete one of Saskatchewan birds, Mr. Speirs feels that its chief interest would be for potential summer visitors to Saskatchewan as an indication of the relative abundance and observability of the roadside species.

Following is the list without details as to where the species were seen:

Holboell's Grebe ...-

Horned Grebe ....... 33

Pied-billed Grebe ..

American Bittern ...-

Mallard

Gadwall

Baldpate

Pintail

Green-winged Teal 1

Blue-winged Teal .-- 11

Shoveller _ 11

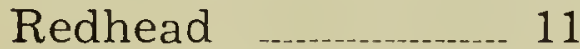

Canvas-back …...... 2

Lesser Scaup Duck .. 16

Ruddy Duck .......... 11

Hooded Merganser .- 1

Red-tailed Hawk ... 6

Swainson's Hawk ...- 13

Marsh Hawk

Hungarian Partridge 21

Ring-necked Pheasant 1

Sora Rail

American Coot ....... 55

Killdeer 31

Wilson's Snipe _.... 2

Upland Plover _...... 3

Spotted Sandpiper ..

Solitary Sandpiper -.

Willet

Lesser Yellow-legs .. 23

Marbled Godwit
American Avocet Ring-billed Gull

Franklin's Gull

Common Tern

Black Tern

Mourning Dove

Nighthawk

Flicker

Downey Woodpecker

Eastern Kingbird 82

Arkansas Kingbird .. 8

Eastern Phoebe

Least Flycatcher

Horned Lark

Tree Swallow

Bank Swallow

Barn Swallow

Cliff Swallow

Purple Martin

Magpie

American Crow

B.-capped Chickadee

House Wren

Long-billed Marsh Wren

Catbird

Brown 'Thrasher

A. Robin

Veery

Mountain Bluebird

Cedar Waxwing

31
1 Loggerhead Shrike _. 34

1 Red-eyed Vireo _..... 6

36 Warbling Vireo __. 2

5 Tennessee Warbler 1

117 Yellow Warbler ..... 61

13 Yellow Throat 5

8 American Redstart .. 1

10 English Sparrow 495

Western Meadowlark 94

Yellow-headed Blackbird

Red-winged

Blackbird

13

Baltimore Oriole

Brewer's Blackbird 444

16 Grackle 6

25 Cowbird _._. 5

4 Rose-breasted

8 Grosbeak 1

3 American Goldfinch 23

Savannah Sparrow 37

Baird's Sparrow _.... 4

Leconte's Sparrow _. 6

Vesper Sparrow _... 94

Chipping Sparrow ... 4

Clay-coloured

$$
\text { Sparrow }
$$

Song Sparrow

Chestnut-collared

Longspur
We hear many stories of long battles between animals and the survival of the fittest, but the following incident show that both were very fit. While harvesting the crop, the men on the combine came to a circle of wheat flattened down. On inves- tigating the cause they found a dead skunk and a dead tomcat torn and blood-caked. This must have been a battle royal. Did poor Tommy die of wounds or the potent weapon of the skunk?-Isabelle Powell, Swift Current. 